Research Article

\title{
Knowledge Mapping of Green Technology Visualization with Bibliometric Tools
}

\author{
Shiliang $\mathrm{Xia}^{1}$ and Kaiyang Zhong $\mathbb{D}^{2}$ \\ ${ }^{1}$ School of Economics and Management, Huaiyin Normal University, Huaian 223001, Jiangsu, China \\ ${ }^{2}$ School of Economic Information Engineering, Southwestern University of Finance and Economics, Chengdu 611130, \\ Sichuan, China \\ Correspondence should be addressed to Kaiyang Zhong; zhongky0626@163.com
}

Received 15 October 2021; Accepted 15 November 2021; Published 27 November 2021

Academic Editor: Le Sun

Copyright ( $) 2021$ Shiliang Xia and Kaiyang Zhong. This is an open access article distributed under the Creative Commons Attribution License, which permits unrestricted use, distribution, and reproduction in any medium, provided the original work is properly cited.

\begin{abstract}
An increasing number of research literature studies about green technology have been accepted by journals of different disciplines due to the rapid technical progress and innovation in all types of industry. This study uses bibliometric tools of CiteSpace and VOSviewer to analyse the key authors' co-citation network, institution cooperation, the keyword clusters of green technology, and the evolution trend of green technology. We find that since 1960s, the number of research papers with green technology theme has been growing. These papers are mainly involved in fields of economics and business, engineering, and chemistry, in which there exist 13 highest cited papers from 2009 to 2020 based on the Web of Science database. In this study, we find the top 20 journals of green technology with the parameter of literature count and centrality. We find that the cooperation of authors is quite weak with the co-authorship analysis, and we obtain the top 12 institutions in 15 countries dominantly in green technology research through country and institution analysis. We conduct a cluster analysis of keywords related to green technology, and we obtain 10 clusters, with three economical clusters, five engineering clusters, and two chemical clusters. Finally, we summarise green technology with the aid of the timeline view function of CiteSpace system.
\end{abstract}

\section{Introduction}

The concept of green technology was put forward in the 1960s due to the social appeal of saving resources and energy consumption, less pollutive output, and less damage to the ecological circle [1]. With the sustainable and ecological revolution of the modern industry, similar concepts of environmental sound technology and ecological technology have been created to conform with technical civilisation. Nowadays, green technology has been widely accepted in different disciplines of philosophy, natural science, economics, and management; however, green technology research has focused quite differently in several disciplines. Some economic researchers have discussed the efficiency improvement of green technology applied on electric charging behaviour and different sizes of farm [2-5]; some chemical papers of green technology dealt with molecular imprinting technology [6] and wastewater treatment [7]; some engineering issues put green technology into textile processing [8], green building practice $[9,10]$, and surface engineering [11]; and even Internet of Things (IoT) technology has been applied in waste water treatment [12]. Moreover, multidisciplinary integrated green technologies are utilised in agriculture, biology, medical, and some other research areas.

The current literature amount with "green technology" in titles in the Web of Science (WoS) database was 1516 by December 31, 2020, with 12 types including common articles, reviews, editorial materials, meeting abstracts, book reviews, and proceeding papers. Of the review papers, 140 literature records reviewed a certain method or technical application [13-15]. Unfortunately, no paper has addressed the present research situation and future trend of green technology with bibliometric tools. Bibliometric tools can 
provide a clear knowledge map of a specific theme. In this study, we use two bibliometric tools, CiteSpace and VOSviewer, to examine the present research status and hot papers, the cooperation network of authors and main institution, and the cluster attribute of green technology [16]. This study attempts to solve three important questions. First, we will show the green technology literature research status according to the publishing and citing trend with three stages. Second, we will use knowledge mapping systems to show the core journals, highly cited papers, and categories of different fields of green technology. Third, cluster and coword analysis will clarify the green technology development themes and the implications of each cluster are provided.

\section{Materials and Methods}

According to the knowledge mapping theory, we can use coword, institution, timeline, and cluster analyses to obtain the research front and the evolutionary trend of a certain theme. In this study, we use the former three analyses with CiteSpace tool and the cluster analysis with VOSviewer software. The analysis data units are collected from the WoS database.

2.1. Data Collection and Literature Search Strategy. WoS is equipped with the global academic literature of different disciplines, and it can provide the citation record of each literature that meets the functional requirements of co-word analysis. We choose the WoS core collection database with the timespan from 1900 to 2020, with citation indexes of Science Citation Index Expanded, Social Science Citation Index, Arts and Humanities Citation Index, and Emerging Sources Citation Index. With the consideration of the accuracy of citation results and some literature references $[17,18]$, we set the retrieval strategy as follows: "TITLE: (green technology) OR TITLE: (Environmental Sound Technology) OR TITLE: (Ecological Technology)". We obtain a total of 1516 relevant papers, and we refine the document types. Then, we obtain 996 "ARTICLE" and 140 "REVIEW" papers, and a total of 1136 papers are the input text files. The data were last updated on December 31, 2020.

2.2. Bibliometric Tools of CiteSpace and VOSviewer. CiteSpace is an information visualisation system developed by Chen (2006) based on Java language; it can give the knowledge map of a specific research domain with co-citation analysis and pathfinder network scaling to seek the key evolutionary path and intellectual turning points [19]. CiteSpace can realise several important functions: it can identify the milestone paper, appraise the innovative extent, and reveal the research front evolution of the knowledge unit. VOSviewer software was developed by the two Netherland scholars van Eck and Waltman. Their paper Software Survey: VOSviewer, a Computer Program for Bibliometric Mapping is a hot paper of the Journal of Informetrics. VOSviewer provides five types of function, including co-authorship analysis, co-occurrence analysis, citation analysis, bibliographic coupling, and co-citation analysis, and the units of analysis can include authors, organisation (institution), and countries. In comparison with CiteSpace, VOSviewer can provide a clearer clustering result due to its parameter set of clustering resolution. The following knowledge mapping analysis of green technology includes four steps (Figure 1): the first step is to select data from the WoS database; the second step is the co-citation analysis to acquire the key literature; the third step is the cooccurrence network analysis; and the fourth step is cluster view analysis to obtain the cluster results of green technology literature.

In VOSviewer, the basic colour view of a theme depends on the ordinary density rule. The colour of a point in the map is determined based on the item density of the point. Let $\bar{d}$ denote the average distance between two items, that is,

$$
\bar{d}=\frac{2}{n(n-1)} \sum_{i \leq j}\left\|x_{i}-x_{j}\right\| .
$$

The item density $\mathrm{D}(x)$ of a point $x=(x 1, x 2)$ is then defined as

$$
D(x)=\sum_{i=1}^{n} w_{i} K\left(\frac{\left\|x-{ }_{x}^{i}\right\|}{h \bar{d}}\right),
$$

where $k:[0, \infty) \longrightarrow[0, \infty)$ denotes a kernel function; $h>0$ denotes a parameter called the kernel width; and $w_{i}$ denotes the weight of item $i$, that is, the total number of occurrences or co-occurrences of item $i$. The kernel function $k$ must be nonincreasing. VOSviewer uses a Gaussian kernel function given by

$$
K(t)=\exp \left(-t^{2}\right)
$$

It follows from (2) that the item density of a point in a map depends on the number of neighbouring items and on the weights of these items. The larger the number of neighbouring items and the smaller the distances between these items and the point of interest is, the higher the item density will be. In addition, the higher the weights of the neighbouring items is, the higher the item density will be.

\section{Results}

\subsection{Yearly Distribution of Green Technology Papers and Highly Cited Paper Analysis}

3.1.1. Yearly Distribution of Green Technology Papers. We search for the green technology papers from the WoS Core Collection. Then, we obtain the number of published articles annually (PN) from 1968 to 2020. The published papers can be divided into three stages: the primary stage (1968-1990), in which the maximum number is below 10; the booming stage (1991-2007), in which the maximum number is below 30; and the prosperous stage (2008-2020), in which the slope ratio of trendline is obviously increasing. For the citation situation analysis, we collect the citation number $(\mathrm{CN})$ of all the green technology papers. The h-index of green technology source is 77 , and the average citation per item is 20.16 . The sum of times cited is 30567 , and that without self-citations is 30066 (Figure 2). As 


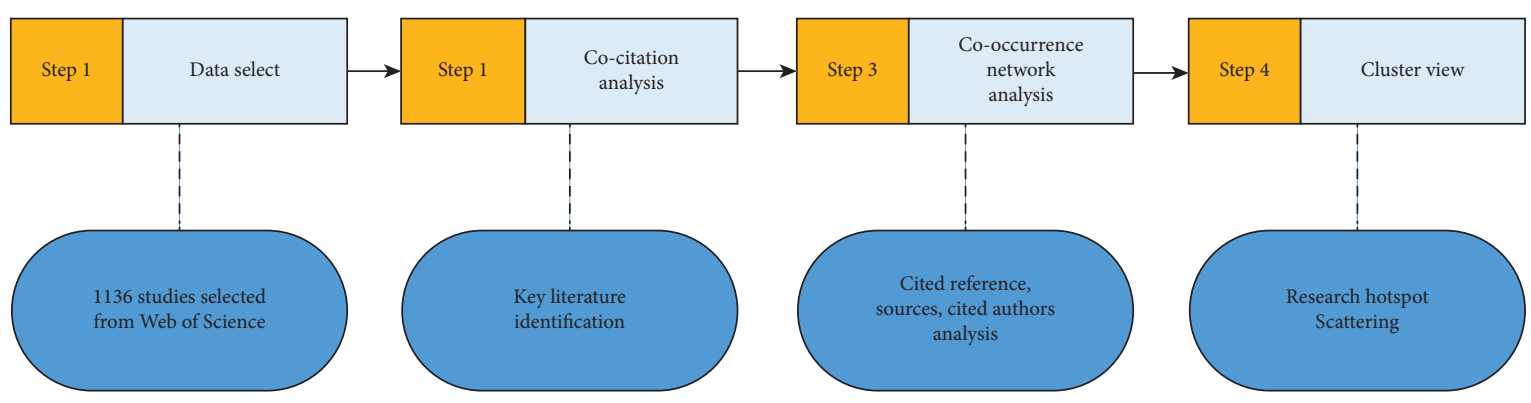

FIgURE 1: Four steps of knowledge mapping analysis.

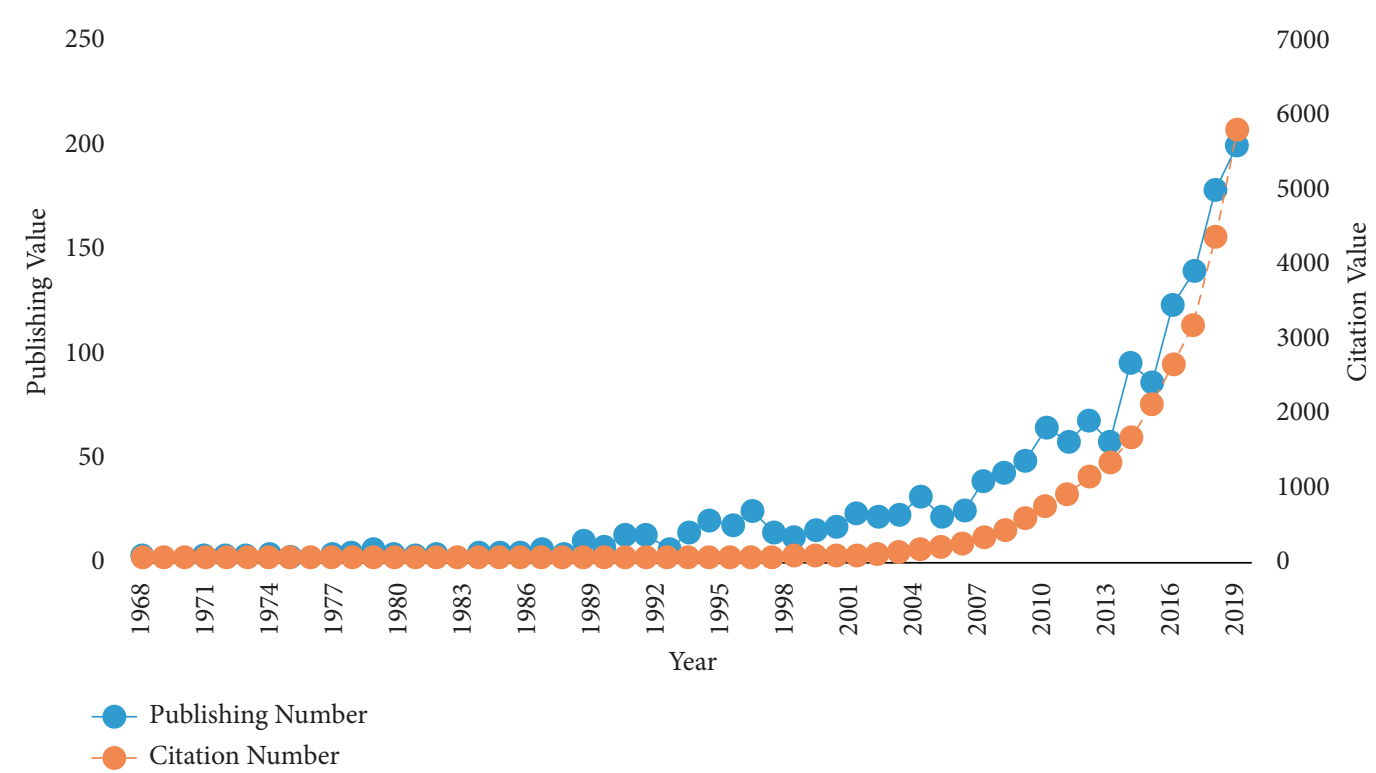

FIgURE 2: Annual PN and CN distribution of green technology.

indicated in Figure 2, green technology theme has attracted increasing academic interest since 1968 .

The 1136 green technology papers involve 149 types of research area, the top ten of which are environmental sciences, green sustainable science technology, engineering environmental, engineering chemical, environmental studies, energy fuels, chemistry multidisciplinary, economics, food science technology, and biotechnology applied microbiology. As shown in Table 1, green technology records of environmental sciences exist, which accounts to $24.47 \%$ of the total records; the last research fields are agriculture and biotechnology applied microbiology, with 49 records of $4.31 \%$ of the total. Surprisingly, management and business categories take up the 11 th and the 12 th positions of all the research areas.

3.1.2. Cited Journal Analysis. In VOSviewer software, we select 1968-2020 with one year per slice as the time slice. To obtain the core journals of green technology, we set the types of citation and "sources" as the unit of analysis. We obtain 716 sources; the total strength of each of the citation links with other sources are calculated. The sources with the greatest total link strength are selected. We find that some of the 716 items in the network are not connected to each other.
The largest set of connected items consists of 91 items (in Figure 3).

We choose the top 20 journals of green technology by the centrality value (Table 2 ). From Table 2 , we can find that the Journal of Cleaner Production has 184 green technology records, whereas the Journal of Agricultural and Food Chemistry has the least 7 records. From the centrality parameter, the value of Journal of Cleaner Production in 2010 is 0.26 , which is the largest, whereas the value of Journal of Agricultural and Food Chemistry in 2005, Journal of the American Chemical Society in 2012, Angewandte Chemie in 2012, and Pure and Applied Chemistry in 2007 is 0.06, which is the least.

3.1.3. Highly Cited Paper Analysis. From the green technology citation results, we can refine papers by highly cited type in the field with data from the Essential Science Indicator (ESI) automatically. Now, ESI ranking is becoming increasingly popular, and the highly cited paper has received sufficient citations to place it in the top of $1 \%$ of different academic fields based on a highly cited threshold for the field and publication year. After we comb the 13 papers of green technology, four papers related to the field of chemistry remain published on Separation and Purification Technology, 
TABLE 1: Research area of green technology records.

\begin{tabular}{lcc}
\hline Research areas & Record count & Percentage of the total records \\
\hline Environmental sciences & 278 & 24.47 \\
Green sustainable science technology & 168 & 14.79 \\
Engineering environmental & 117 & 10.30 \\
Engineering chemical & 114 & 10.03 \\
Environmental studies & 95 & 8.36 \\
Energy fuels & 88 & 7.75 \\
Chemistry multidisciplinary & 78 & 6.87 \\
Economics & 72 & 6.34 \\
Food science technology & 59 & 5.19 \\
Biotechnology applied microbiology & 49 & 4.31 \\
\hline
\end{tabular}
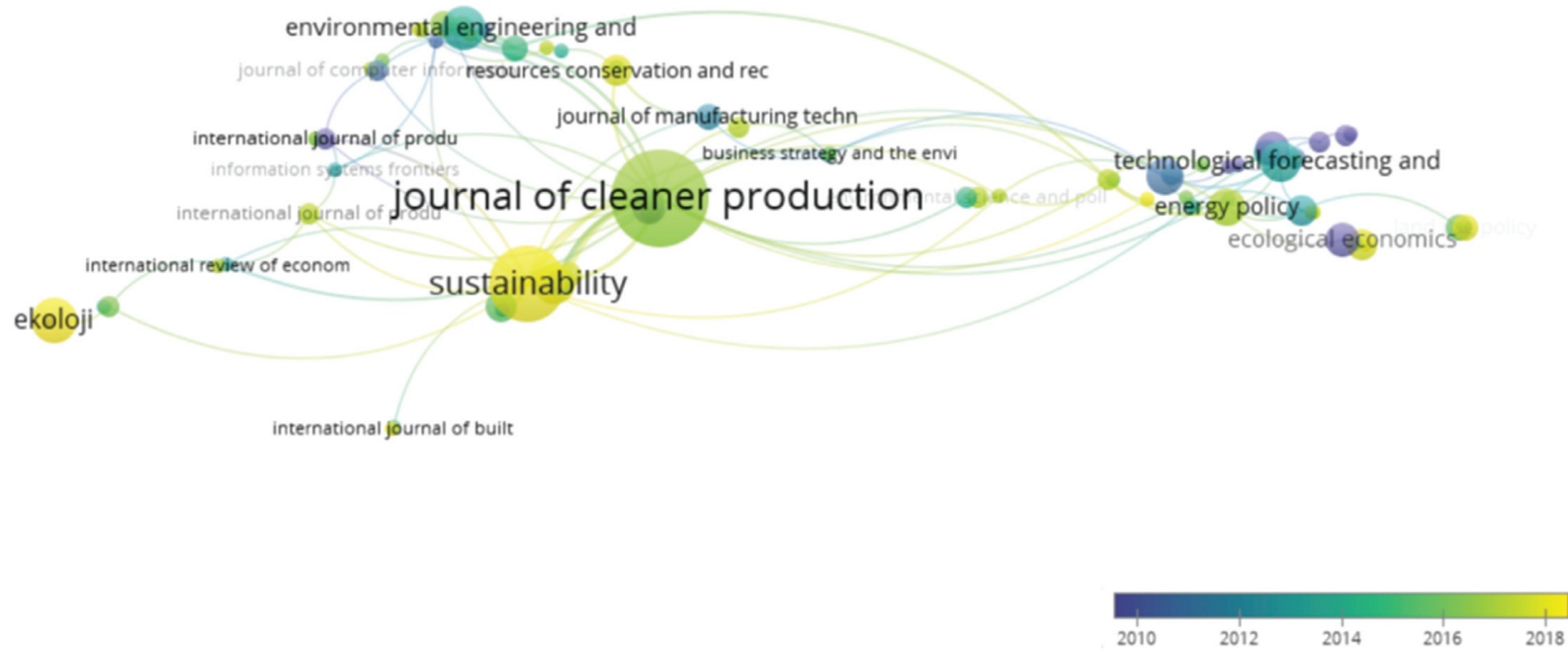

FIGURE 3: Cited journal mapping of green technology.

TABle 2: Parameters of green technology cited journals.

\begin{tabular}{lcccc}
\hline & Count & Centrality & Year & Cited journals \\
\hline 1 & 184 & 0.26 & 2010 & Journal of Cleaner Production \\
2 & 39 & 0.24 & 2011 & Resources Conservation and Recycling \\
3 & 45 & 0.16 & 2006 & Environmental Science and Technology \\
4 & 105 & 0.13 & 2002 & Science \\
5 & 101 & 0.13 & 1980 & Journal of Hazardous Materials \\
6 & 66 & 0.13 & 2010 & Industrial and Engineering Chemistry Research \\
7 & 82 & 0.12 & 2006 & Bioresource Technology \\
8 & 65 & 0.12 & 2005 & Chemical Review \\
9 & 81 & 0.11 & 2005 & MIS Quarterly \\
10 & 40 & 0.11 & 2007 & Journal of Chemical Technology and Biotechnology \\
11 & 35 & 0.10 & 2010 & Renewable and Sustainable Energy Reviews \\
12 & 48 & 0.09 & 2011 & Energy Policy \\
13 & 128 & 0.08 & American Economic Review \\
14 & 120 & 0.07 & Energy Economics \\
15 & 59 & 0.07 & 2004 & Journal of Organic Chemistry \\
16 & 29 & 0.07 & Research Policy \\
17 & 67 & 0.06 & 2005 & Journal of Agricultural and Food Chemistry \\
18 & 51 & 0.06 & 2012 & Journal of the American Chemical Society \\
19 & 38 & 0.06 & Angewandte Chemie \\
20 & 0.06 & & Pure and Applied Chemistry
\end{tabular}


Journal of Supercritical Fluids, Analytica Chimica Acta, and Fuel Processing Technology Journal. These papers deal with electrocoagulation technique [20], supercritical fluid extraction [21], eutectic solvents [22], and biodiesel focusing on green catalytic techniques [23], which introduce certain new applicable techniques or methods for reducing pollutive outputs or promote production efficiency.

There are four papers related to the field of engineering published on the International Journal of Production Economics, Chemical Engineering Journal, Solar Energy, and Production and Operations Management Journal. These four papers examine carbon emission reductions under market mechanism [24], membrane bioreactor technology in waste water treatment [25], green roofs technology to mitigate the heat island phenomenon [26], and environmental taxes and subsidies motivating the consumer's choice of green emission technology [27].

Four papers are related to the field of economics and business published on Management Decision, Management Science, R\&D Management, and Journal Of Environmental Economics and Management. These papers discuss the productive technical progress and green technical innovation in China [28], the potential effects of governmental subsidies for green technology adoption in view of the manufacturing industry's response [29], the current overview of green innovation management [30], and American consumer adoption of hybrid-electric vehicles [31]. One paper is related to the field of geosciences, which is about metals for green technology application and published on Ore Geology Reviews [32].

As shown in Table 3, the highest citation count is the "Natural deep eutectic solvents as new potential media for green technology" by Dai et al. (2013), with a total number of 587; and the lowest citation count is "Electrocoagulation as a green technology for phosphate removal from river water" by Hashim et al. (2019).

\subsection{Co-Authorship Analysis of Green Technology Research.} We use the VOSviewer co-authorship function to create a map of co-authorship of green technology. We click the type of analysis item and choose the "Authors" unit of analysis; for the counting method, we choose "Full counting." We set the minimum number of documents of an author default threshold value as 3, and of all the 4158 authors, 54 authors meet the thresholds (Figure 4). For each of the 54 authors, the total strength of the co-authorship links with each other author is calculated automatically. The authors with the greatest total link strength is selected. The result can be adjusted with documents, citations, and total link strength parameter.

As shown in Figure 4, the co-author distribution of green technology is quite scattered. Moreover, we obtain three small co-authorship networks. The first network, indicated by red colour, includes three authors belonging to the economic field; they mainly contribute to the strategies, barriers, and critical drivers of green building technology adoption in developing countries, with the cases of Ghana and developed countries, such as the USA $[10,33,34]$. The second network, indicated by blue colour, includes five authors belonging to the bio- engineering field; these authors investigate the adoption of green fertilizer technology (GFT) among Malaysian farmers in the paddy industry, which may be a possible solution for Malaysian food security $[35,36]$. The third network, indicated by green colour, includes eight authors belonging to the chemistry field; they suggest green methods for the production of high fatty acid starch esters without the use of solvent and additives [37].

3.3. Country and Institution Analysis. Country and institution analysis in knowledge mapping can reflect the number distribution of research papers and the cooperation of different institutions and countries. The node size reflects the number, and the link value between nodes reflects the strength of co-authorship. Figure 5 shows the top three countries, USA, China, and England, which have co-authorship with one another to some extent.

From Table 4, we can obtain the top 15 countries or regions of green technology, namely, the USA, China, England, Australia, Canada, France, Italy, Spain, Germany, Malaysia, Japan, South Korea, Taiwan, Finland, and the Netherlands. From the Documents column, 301 green technology records in the USA rank first among all the countries, followed by China with 205 documents and England with 72 documents, and the last country is Finland with 16 documents. From the Citations column, the USA still ranks first with 5877 citations, followed by Canada with 1763 and China with 1703, and the lowest country is Finland, with 335 citations. From the Total link strength column, the top three countries are the USA, China and England with total link strength of 108 , 99, and 65 , respectively, and the last two countries are Finland and the Netherlands, with the same value of total link strength of 21 .

For institution analysis, there exist 1575 research organisations all over the world with publishing papers with green technology issues. We set the minimum number of documents of an organisation threshold value as 7, and 12 research institutions meet the threshold, of which three institutions are in Malaysia (Univ Sains Malaysia, Univ Malaya, and Univ Teknol Malaysia), two institutions are in China (Chinese Acad Sci and Hongkong Polytec Univ), two institutions are in Canada (Mcgill Univ and Queens Univ), one institution is in South Korea (Seoul Natl Univ), one institution is in Jordan (Jordan Univ Sci and Technol), one institution is in the USA (Texas A\&M Univ), one institution is in the UK (Univ Nottingham), and one institution is in Italy (Univ Turin). As shown in Table 5, Chinese Acad Sci, which is the top institution, has 19 documents of green technology. Mcgill Univ has 549 most citations of green technology. The total link strength value indicates that the correlation between institutions is quite weak, and individual organisation has limited academic influence.

\subsection{Keyword Cluster Analysis}

3.4.1. Green Technology Cluster Analysis. Keyword cluster analysis can reveal the specific theme's present situation and research front. Cluster analysis can detect homogeneous 
TABLE 3: Highly cited papers of green technology.

\begin{tabular}{|c|c|c|c|c|c|c|}
\hline & Author & Paper title & Journal title & Field & $\begin{array}{c}\text { Citation } \\
\text { counts }\end{array}$ & $\begin{array}{l}\text { Published } \\
\text { year }\end{array}$ \\
\hline 1 & Hashim > et al. & $\begin{array}{l}\text { Electrocoagulation as a green technology for } \\
\text { phosphate removal from river water }\end{array}$ & $\begin{array}{l}\text { Separation and } \\
\text { Purification Technology }\end{array}$ & Chemistry & 21 & 2019 \\
\hline 2 & Song and Wang & $\begin{array}{l}\text { Market competition, green technology } \\
\text { progress and comparative advantages in } \\
\text { China }\end{array}$ & Management Decision & $\begin{array}{l}\text { Economics } \\
\text { and business }\end{array}$ & 36 & 2018 \\
\hline 3 & $\mathrm{Xu}, \mathrm{He}$, and $\mathrm{Xu}$ & $\begin{array}{l}\text { Supply chain coordination with green } \\
\text { technology under cap-and-trade regulation }\end{array}$ & $\begin{array}{l}\text { International Journal of } \\
\text { Production Economics }\end{array}$ & Engineering & 60 & 2017 \\
\hline 4 & $\begin{array}{l}\text { Cohen, Lobel, and } \\
\text { Parakis }\end{array}$ & $\begin{array}{c}\text { The impact of demand uncertainty on } \\
\text { consumer subsidies for green technology } \\
\text { adoption }\end{array}$ & Management Science & $\begin{array}{l}\text { Economics } \\
\text { and business }\end{array}$ & 50 & 2016 \\
\hline 5 & $\begin{array}{l}\text { Neoh, Noor, and } \\
\text { Mutamim }\end{array}$ & $\begin{array}{c}\text { Green technology in wastewater treatment } \\
\text { technologies: Integration of membrane } \\
\text { bioreactor with various wastewater } \\
\text { treatment systems }\end{array}$ & $\begin{array}{l}\text { Chemical Engineering } \\
\text { Journal }\end{array}$ & Engineering & 92 & 2016 \\
\hline 6 & $\begin{array}{l}\text { De Melo, Silcestre, } \\
\text { and Silva }\end{array}$ & $\begin{array}{c}\text { Supercritical fluid extraction of vegetable } \\
\text { matrices: Applications, trends and future } \\
\text { perspectives of a convincing green } \\
\text { technology }\end{array}$ & $\begin{array}{l}\text { Journal of Supercritical } \\
\text { Fluids }\end{array}$ & Chemistry & 170 & 2014 \\
\hline 7 & Santamouris & $\begin{array}{c}\text { Cooling the cities - a review of reflective and } \\
\text { green roof mitigation technologies to fight } \\
\text { heat island and improve comfort in urban } \\
\text { environments }\end{array}$ & Solar Energy & Engineering & 511 & 2014 \\
\hline 8 & $\begin{array}{l}\text { Krass, Nedorezov } \\
\text { and Ovchinnikov }\end{array}$ & $\begin{array}{l}\text { Environmental taxes and the choice of green } \\
\text { technology }\end{array}$ & $\begin{array}{l}\text { Production and } \\
\text { Operations } \\
\text { Management }\end{array}$ & Engineering & 149 & 2013 \\
\hline 9 & $\begin{array}{l}\text { Hein, Mizell, and } \\
\text { Koschinsky }\end{array}$ & $\begin{array}{l}\text { Deep-ocean mineral deposits as a source of } \\
\text { critical metals for high- and green } \\
\text { technology applications: Comparison with } \\
\text { land-based resources }\end{array}$ & Ore Geology Reviews & Geosciences & 202 & 2013 \\
\hline 10 & $\begin{array}{l}\text { Dai, van Spronsen, } \\
\text { and Witkamp }\end{array}$ & $\begin{array}{l}\text { Natural deep eutectic solvents as new } \\
\text { potential media for green technology }\end{array}$ & Analytica Chimica Acta & Chemistry & 587 & 2013 \\
\hline 11 & $\begin{array}{l}\text { Schiederig, Tietze, } \\
\text { and Herstatt }\end{array}$ & $\begin{array}{c}\text { Green innovation in technology and } \\
\text { innovation management - an exploratory } \\
\text { literature review }\end{array}$ & ReD Management & $\begin{array}{l}\text { Economics } \\
\text { and business }\end{array}$ & 169 & 2012 \\
\hline 12 & $\begin{array}{l}\text { Gallagher and } \\
\text { Muehlegger }\end{array}$ & $\begin{array}{l}\text { Giving green to get green? Incentives and } \\
\text { consumer adoption of hybrid vehicle } \\
\text { technology }\end{array}$ & $\begin{array}{l}\text { Journal of } \\
\text { Environmental } \\
\text { Economics and } \\
\text { Management }\end{array}$ & $\begin{array}{l}\text { Economics } \\
\text { and business }\end{array}$ & 260 & 2011 \\
\hline 13 & $\begin{array}{l}\text { Helwani, Othman, } \\
\text { and Aziz }\end{array}$ & $\begin{array}{c}\text { Technologies for production of biodiesel } \\
\text { focusing on green catalytic techniques: A } \\
\text { review }\end{array}$ & $\begin{array}{l}\text { Fuel Processing } \\
\text { Technology }\end{array}$ & Chemistry & 344 & 2009 \\
\hline
\end{tabular}

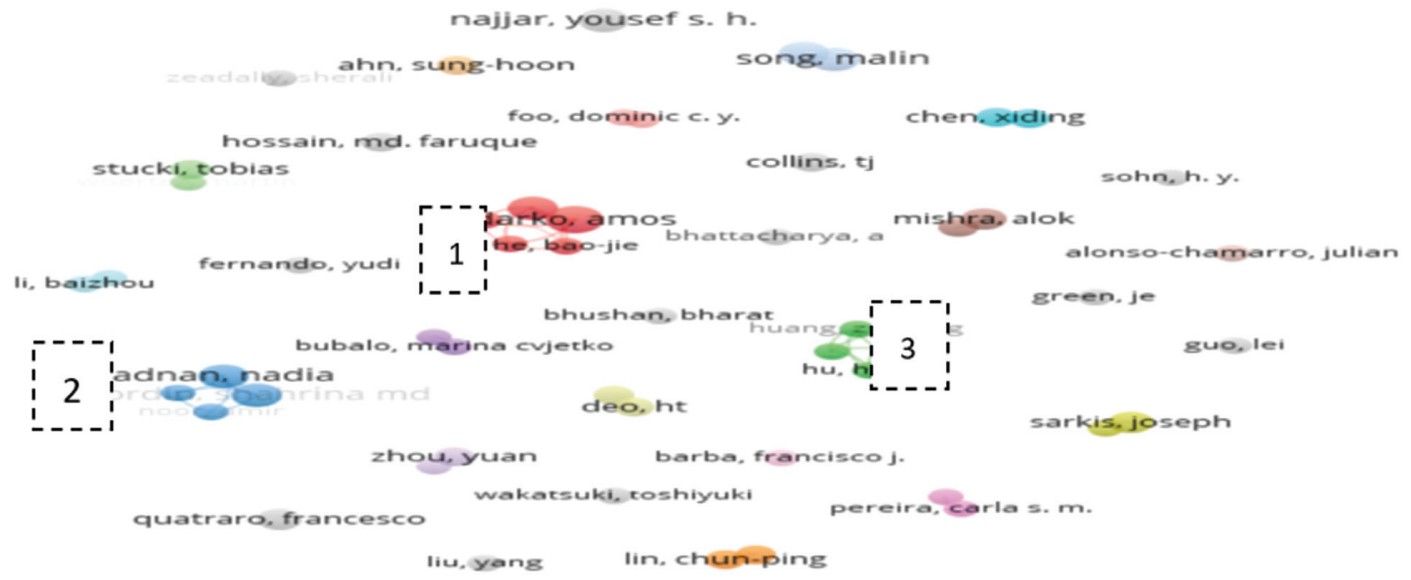

FIGURE 4: Co-authorship analysis of green technology. 


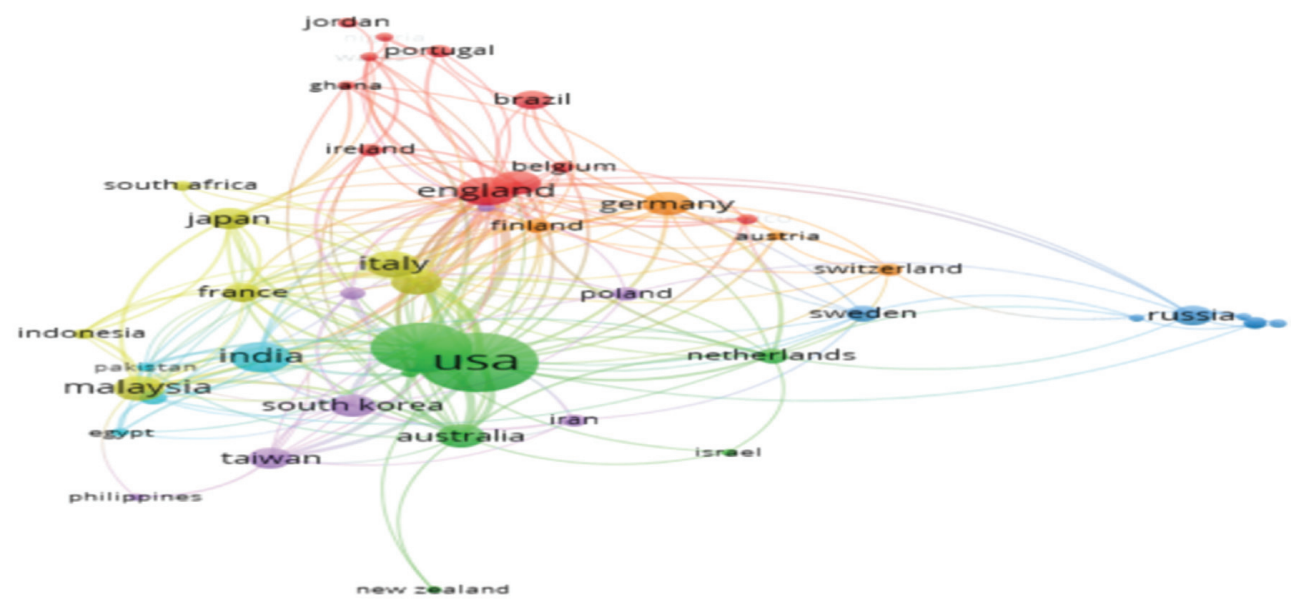

FIGURE 5: Co-authorship mapping of different countries.

TABLE 4: Green technology co-authorship of different countries or regions.

\begin{tabular}{lcccc}
\hline & Country & Documents & Citations & Total link strength \\
\hline 1 & USA & 301 & 5877 & 108 \\
2 & China & 205 & 1703 & 99 \\
3 & England & 72 & 1632 & 65 \\
4 & Australia & 50 & 1157 & 41 \\
5 & Canada & 53 & 1763 & 34 \\
6 & France & 29 & 420 & 34 \\
7 & Italy & 60 & 571 & 33 \\
8 & Spain & 49 & 684 & 32 \\
9 & Germany & 49 & 1005 & 29 \\
10 & Malaysia & 51 & 866 & 29 \\
11 & Japan & 39 & 526 & 27 \\
12 & South Korea & 41 & 772 & 24 \\
13 & Taiwan & 40 & 395 & 24 \\
14 & Finland & 16 & 335 & 21 \\
15 & Netherlands & 21 & 862 & 2 \\
\hline
\end{tabular}

TABle 5: Green technology co-authorship of different institutions.

\begin{tabular}{lcccc}
\hline & Institution & Documents & Citations & Total link strength \\
\hline 1 & Univ Sains Malaysia & 9 & 481 & 2 \\
2 & Chinese Acad Sci & 19 & 127 & 124 \\
3 & Seoul Natl Univ & 10 & 146 & 1 \\
4 & Univ Malaya & 7 & 92 & 1 \\
5 & Univ Teknol Malaysia & 7 & 195 & 1 \\
6 & Hongkong Polytec Univ & 10 & 112 & 0 \\
7 & Jordan Univ Sci and Technol & 9 & 549 & 0 \\
8 & Mcgill Univ & 8 & 191 & 0 \\
9 & Queens Univ & 7 & 139 & 0 \\
10 & Texas A\&M Univ & 7 & 436 & 0 \\
11 & Univ Nottingham & 9 & 73 & 0 \\
12 & Univ Turin & 8 & & 0 \\
\hline
\end{tabular}

units using an algorithm method [38]. In contrast to other meta-analysis methods, cluster calculation has been proved to have less subjective bias, and strong connections of units reflect the specific theme in the same field [39]. The co-word matrix is commonly constructed from the samples, and statistical variables are used to measure the degree of similarity of indicators. According to different similarities, closely related objects are gathered automatically, which denote the direct connections among keywords or titles in knowledge mapping software. The CiteSpace system 
provides five types of visualisation style, namely, cluster view, timeline view, timezone view, geographic overlay, and dual-map overlay. The cluster and timeline views are the most popular. The cluster view can reflect the distribution of research area in different dimensions, and the timeline view can tell us the yearly evolution and interaction of each cluster. Two important parameters indicate the quality of cluster mapping, namely, modularity and silhouette values. Generally, if the modularity value is greater than 0.3 , then the cluster is significant; if the mean silhouette value is greater than 0.5 , then the cluster view is reasonable and acceptable. First, we perform the cluster view operation. The results indicate that the merged network of keywords related to green technology consists of 352 nodes and 1684 links. The parameter modularity value is 0.5225 , and the mean silhouette value is 0.6082 (Figure 6).

From the statistical results of the keywords from the yearly slice (Table 6), we choose the top 10 keywords of the green technology cluster. The top 10 keywords are emission, green technology, performance, energy, design, optimisation, system, behaviour, environment, and product. The maximum value of centrality is 0.15 , and the minimum value is 0.07 . From the year distribution, we find that the significant nodes range from 2008 to 2015 .

3.4.2. Timeline View Evolutionary Analysis of Green Technology. The timeline view in the CiteSpace system can reflect the relationship between clusters and historic duration of the literature. In the timeline view, the horizontal axis is the year distribution and the vertical axis is the labelling of the clusters. Keywords belonging to the same cluster are set in a line according to the date of the published literature. In the timeline view, we can obtain the beginning year of a cluster, the numerical trend of a cluster, and the important literature with high betweenness centrality value. From the timeline view of green technology (Figure 7), 10 clusters are labelled with \#0-\#9 and the distribution of clusters mainly focuses from 1998 to 2020.

In the CiteSpace system, the cluster labelling comes from the citing articles based on three types of algorithms: TF * IDF, log-likelihood rate, and mutual information. Given that the consciousness of mapping and log-likelihood ratio value can provide quantifying information automatically, we choose log-likelihood rate algorithm. The labelling results and log-likelihood ratio value of green technology clusters are as follows (Table 7). The first cluster labelling is resource-based view, with a total size of 61 keywords, and the mean year is 2014. Under the line, we can see that the first cluster keywords include adoption, green technology impact, sustainability, renewable energy, environmental policy, green cleaner production, and empirical evidence. The second cluster labelling is green technology progress, with a total size of 55 keywords, and the mean year is 2015; it includes keywords of information technology, remote sensing, energy efficiency, green growth, environmental strategy, and environmental regulation. The third cluster is labelled with BR, with a total of 50 keywords and the mean year of 2016; keywords include life cycle assessment, emission, fuel cell, heavy metal, electric vehicle, catalyst, and eco-design. The fourth cluster is labelled with molecular weight, with a total size of 40 keywords and the mean year of 2015; keywords include degradation, green kinetics, fermentation, biodegradation mechanism, polymer, fabrication, and health. The fifth cluster is labelled with ultrasoundassisted extraction, with a total size of 37 keywords and the mean year of 2016; it includes keywords of polymerisation, carbon dioxide, superficial, subcritical water, plant, and assisted extraction. The sixth cluster is labelled with green revolution, with a total size of 31 keywords and the mean year of 2015; it includes keywords of green technology, rice production, social responsibility, supply chain, and environmental prevention. The seventh cluster is labelled with green building technologies, with a total size of 31 keywords and the mean year of 2015; it includes keywords of environment management, design, investment policy, green economy, sustainable development, green building, critical success factor, and barrier. The eighth cluster is labelled with paper mill waste, with a total size of 19 keywords and the mean year of 2012; keywords of this cluster include water, biosorption waste, ironic liquid, acid extraction, recycling, and aqueous solution. The ninth cluster is labelled with organic peroxide, with a total size of 5 keywords and the mean year of 2012; keywords include SADT, organic peroxide, and accelerating decomposition temperature. The tenth cluster is labelled with alginate, with a total size of 3 keywords and the mean year of 2014; it includes keywords of bacteria, Escherichia coli, and temperature.

3.4.3. Brief Summary of the 10 Clusters. From Table 8, all the papers about green technology can be divided as follows: three clusters are in the economics and business field, five clusters are in the engineering field, and two clusters are in the chemistry field.

The \#0 cluster deals with sustainability, with research subjects mainly about sustainability, supply chain, human resources management, and carbon dioxide emission. Resource-based view theory, which was proposed by Birger Wernerfelt, is an important source of modern core competitive compacity of firms [40]. Each market entity should pay attention to allocate human resources, currency capital, and technology to achieve a more desirable output. Green information technologies and systems refer to initiatives and programs that directly or indirectly address environmental sustainability in organisations [41]. In this cluster, environmental technologies are used in supply chain management to check the collaboration effect between suppliers and customers [42] and corporate sustainable capability may be integrated with information technology and supply chain [43].

The \#1 cluster concentrates on the green technology progress and innovations in different industries. It includes research subjects of green technology progress, adoption decision, Bayesian learning, energy efficiency, and green growth. Topics include energy strategy should be transformed, hydrogen economy as a greener choice as a carbonfree carrier [44], green building technologies adoption [33], 


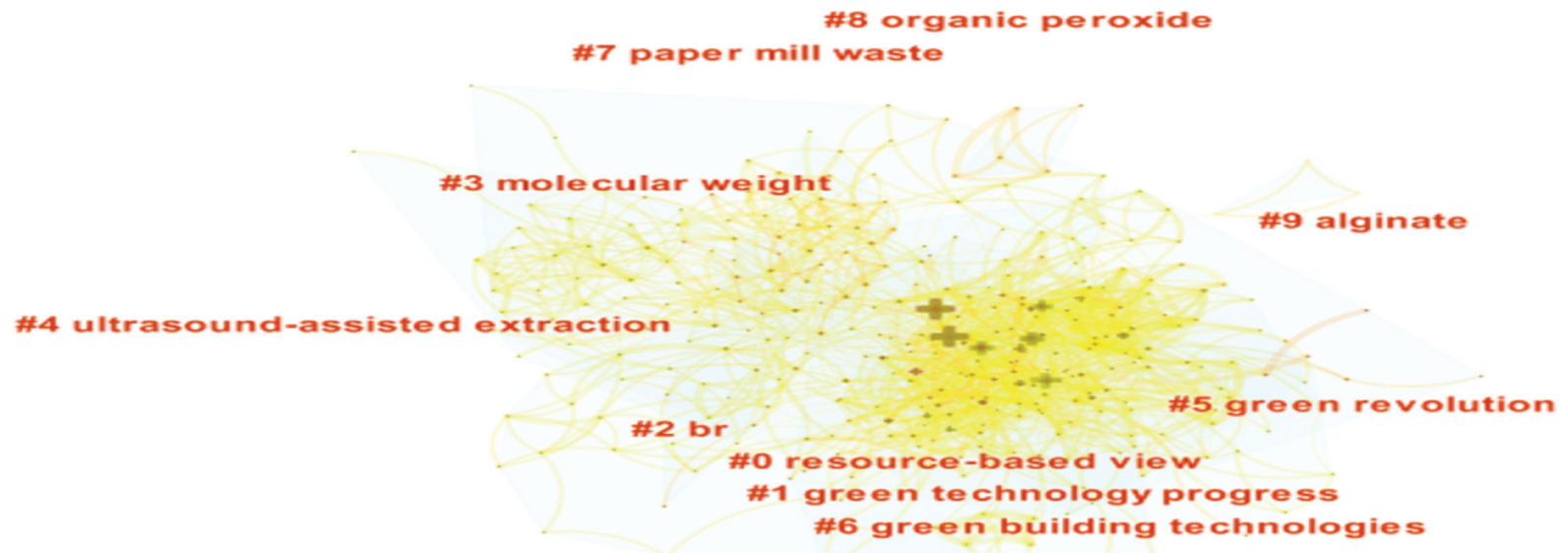

Figure 6: Keyword cluster of green technology.

TABle 6: Top 10 keywords in the green technology cluster.

\begin{tabular}{lccc}
\hline Count & Centrality & Year & Keywords \\
\hline 24 & 0.15 & 2009 & Emission \\
89 & 0.14 & 2010 & Green technology \\
71 & 0.11 & 2013 & Performance \\
32 & 0.10 & 2012 & Energy \\
20 & 0.09 & 2011 & Design \\
60 & 0.09 & 2013 & Optimisation \\
15 & 0.08 & 2008 & System \\
18 & 0.08 & 2011 & Behaviour \\
9 & 0.07 & 2010 & Environment \\
15 & 0.07 & 2015 & Product \\
\hline
\end{tabular}

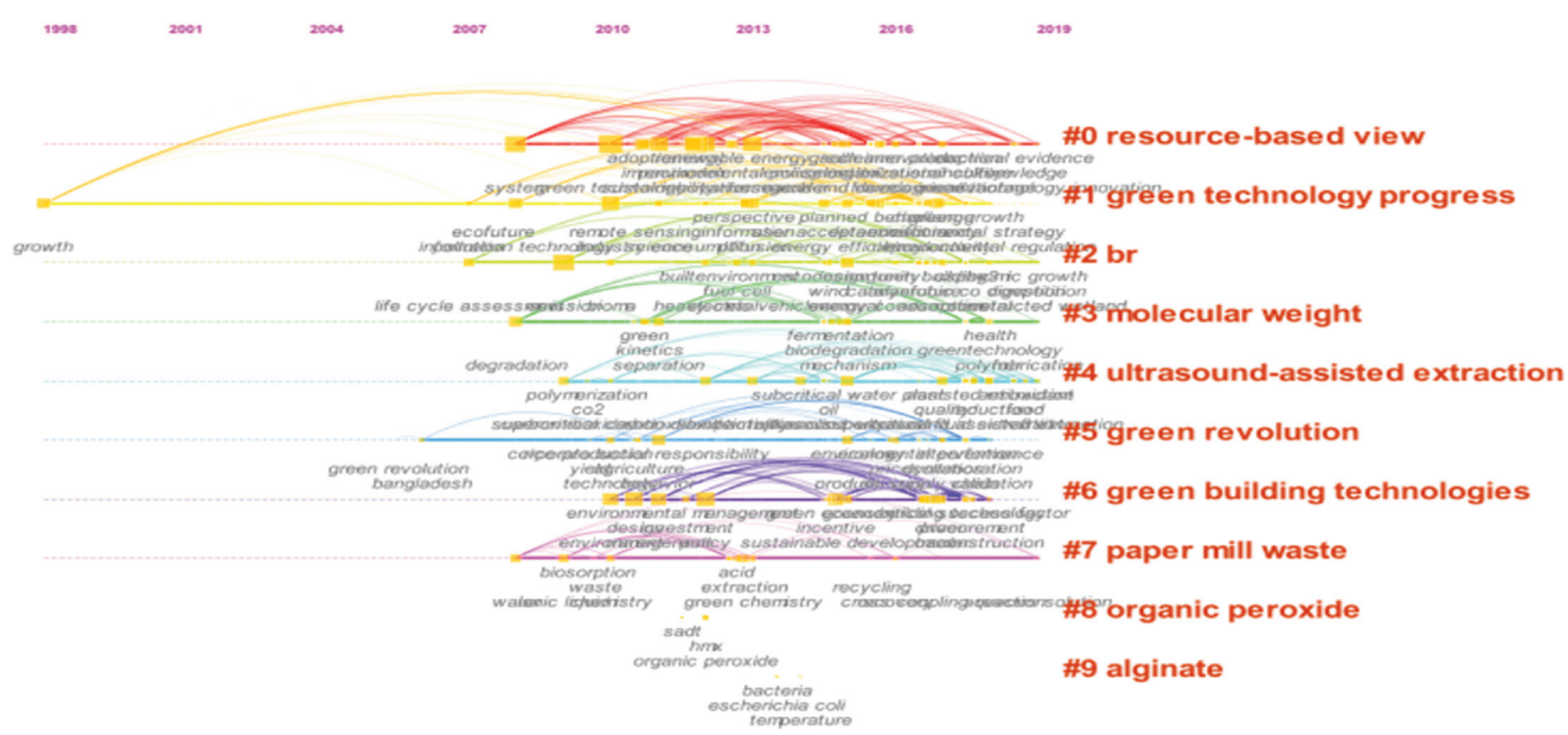

Figure 7: Timeline view of green technology. 
TABLE 7: 10 keyword clusters of green technology.

\begin{tabular}{|c|c|c|c|}
\hline $\begin{array}{l}\text { Cluster } \\
\text { ID }\end{array}$ & Size & $\begin{array}{c}\text { Mean } \\
\text { year }\end{array}$ & Top 10 terms (log-likelihood ratio value) \\
\hline 0 & 61 & 2014 & $\begin{array}{c}\text { Resource-based view (9.35); geothermal energy (6.22); employment (6.22); institutional theory (6.22); } \\
\text { ecological modernisation (6.22); climate change (6.22); innovation (5.32); sustainability (4.1); evaluation } \\
\text { (3.11); manufacturing (3.11) }\end{array}$ \\
\hline 1 & 55 & 2015 & $\begin{array}{l}\text { Green technology progress (15.31); adoption (7.63); TPB (7.63); big data (7.63); GFT (7.63); pollutant } \\
\text { discharge (3.8); software-defined networks (3.8); IoT (3.8); adoption decision (3.8); Bayesian learning (3.8) }\end{array}$ \\
\hline 2 & 50 & 2016 & $\begin{array}{l}\text { BR (7.92); CL (7.92); leaching (7.92); BIM technology (7.92); fuel cells (7.92); application (7.92); nanocrystal } \\
\text { (7.92); diode (7.92); detoxification (7.92); CsPbX3 (7.92) }\end{array}$ \\
\hline 3 & 40 & 2015 & $\begin{array}{c}\text { Molecular weight (9.62); branched structure (9.62); biodegradation (9.62); membrane separations (4.8); } \\
\text { chromatography (4.8); fly ash geopolymer (4.8); mesophase (4.8); chain degradation (4.8); saccharification } \\
(4.8) \text {; criteria weighting (4.8) }\end{array}$ \\
\hline 4 & 37 & 2016 & $\begin{array}{l}\text { Ultrasound-assisted extraction (12.99); antioxidant (8.64); supercritical fluid extraction (8.64); } \\
\text { polycaprolactone (4.31); supercritical extraction (4.31); antioxidant activity (4.31); ellagitannins (4.31); tough } \\
\text { external peels (4.31); green extraction technologies (4.31) }\end{array}$ \\
\hline 5 & 31 & 2015 & $\begin{array}{l}\text { Green revolution (15.23); sawah (10.12); chemical properties (5.04); cap-and-trade (5.04); smartphones (5.04); } \\
\text { information technology managers (5.04); mealtime (5.04); exchangeable cations (5.04); rice production (5.04); } \\
\text { total carbon (5.04) }\end{array}$ \\
\hline 6 & 31 & 2015 & $\begin{array}{l}\text { Green building technologies (30.75); promotion strategies (20.37); construction industry (20.37); barriers } \\
\text { (20.374); sustainable development (20.3); drivers (15.23); Ghana (10.9); developing countries (10.9); } \\
\text { construction market (10.125); new economy (10.12) }\end{array}$ \\
\hline 7 & 19 & 2012 & $\begin{array}{c}\text { Paper mill waste (5.29); botanical (5.29); herbal preparation (5.29); quality control (5.29); environmental } \\
\text { assessment tool (eat) (5.29); ozonation (5.29); biopolymers (5.29); green chemistry (5.29); recycled paper } \\
\text { (5.29); municipal solid waste (5.29); }\end{array}$ \\
\hline 8 & 5 & 2012 & $\begin{array}{l}\text { Organic peroxide (15.17); vent sizing package ( } 7.53) \text {; thermal hazard (7.53); differential scanning calorimetry } \\
\text { (7.53); thermokinetic parameters (7.53); consumption energy (7.53); safety parameter (7.53); diffusion (7.53); } \\
\text { kinetic (7.53) }\end{array}$ \\
\hline 9 & 3 & 2014 & $\begin{array}{l}\text { Alginate (6.77); bacterial inactivation (6.77); silica gel (6.77); catalyst (6.77); immobilisation (6.77); energy } \\
\text { sustainability (6.77); antimicrobial activity (6.77); bacteria (6.77); organic Rankine cycle (6.77) }\end{array}$ \\
\hline
\end{tabular}

TABLE 8: Summary of research subjects of 10 green technology clusters.

\begin{tabular}{|c|c|c|c|}
\hline & Cluster labelling & Field & Research subjects \\
\hline \#0 & Resource-based view & $\begin{array}{l}\text { Economics and } \\
\text { business }\end{array}$ & $\begin{array}{l}\text { (1) Sustainability; (2) supply chain; (3) human resources management; (4) carbon } \\
\text { dioxide emission }\end{array}$ \\
\hline$\# 1$ & $\begin{array}{l}\text { Green technology } \\
\text { progress }\end{array}$ & $\begin{array}{l}\text { Economics and } \\
\text { business }\end{array}$ & (1) Green technology progress; (2) paddy farmer; (3) energy efficiency; (4) green growth \\
\hline$\# 2$ & $\mathrm{BR}$ & Engineering & $\begin{array}{l}\text { (1) Green engineering construction; (2) energy conservation; (3) emerging vehicle } \\
\text { technology; (4) coal utilisation; (5) biotechnology }\end{array}$ \\
\hline \#3 & Molecular weight & Chemistry & (1) Bioremediation; (2) biodegradation; (3) membrane separations; (4) chromatography \\
\hline \#4 & $\begin{array}{l}\text { Ultrasound-assisted } \\
\quad \text { extraction }\end{array}$ & Engineering & (1) Clean extraction; (2) green solvents \\
\hline \#5 & Green revolution & $\begin{array}{c}\text { Economics and } \\
\text { business }\end{array}$ & $\begin{array}{l}\text { (1) Rice production; (2) information technology; (3) financial services industry; (4) } \\
\text { environmental sustainability }\end{array}$ \\
\hline \#6 & $\begin{array}{l}\text { Green building } \\
\text { technologies }\end{array}$ & Engineering & $\begin{array}{l}\text { (1) Promotion strategies; (2) construction market; (3) driving force; (4) technologies } \\
\text { adoption }\end{array}$ \\
\hline \#7 & Paper mill waste & Engineering & $\begin{array}{l}\text { (1) Green chemistry; (2) environmental assessment; (3) paper mill waste; (4) municipal } \\
\text { solid waste }\end{array}$ \\
\hline \#8 & Organic peroxide & Chemistry & $\begin{array}{l}\text { (1) Organic peroxide; (2) scanning calorimetry; (3) incompatible material; (4) thermal } \\
\text { hazard }\end{array}$ \\
\hline$\# 9$ & Alginate & Engineering & (1) Alginate; (2) bacterial inactivation; (3) silica gel; (4) catalyst \\
\hline
\end{tabular}

green technology progress measurement of thermoelectric enterprises [45], green technology progress influencing factors [46], and technological progress in green cement industry [47].

The \#2 cluster explores types of new green technology applicable in chemical and biological engineering. The research subjects are mainly about green engineering construction, energy conservation, emerging vehicle technology, coal utilisation, and biotechnology. The hot topics of this cluster include network energy-saving technologies in mobile industry [48], future wireline networks' potential economic and environmental consequences [49], smart cities and green growth based on universal infrastructure and green technologies [50], and electric vehicle routing designing and technology to recharge [51]. 
The \#3 cluster offers a series of microstructural practices and inner material structure exploratory research. It includes research subjects of bioremediation, biodegradation, membrane separations, and chromatography. These green technologies include phytoremediation technology using diverse plants to remediate contaminated environments [52], polysaccharides modification [53], ferrate as an efficient agent for the abatement of pollutants in water [54], and sorption membrane for water purification and liquid separation $[55,56]$.

The \#4 cluster reveals environmentally friendly extraction mechanism of green extraction kinetics and polymerisation processing technologies. The research subjects are mainly about ultrasound-assisted extraction, supercritical fluid extraction, extraction kinetics, clean extraction, polymer blends, and biomedical polymers. Topics include cleaner production purposes embracing supercritical fluid extraction [21], enhancing aqueous extraction processes without using solvents with ultrasound-assisted extraction technology [57], developing green solvents for oil extraction [58], promoting innovation of more environmentally friendly and tuneable solvents [59], and exploring green catalytic techniques of homogeneous liquids and heterogeneous solids in biodiesel production [23].

The \#5 cluster manifests the social information learning of green revolution in agricultural technology adoption and environmental performance, especially with the cap-andtrade carbon dioxide emission constraint. It includes research subjects of rice production, information technology, financial services industry, and environmental sustainability. It includes discussions on the proper farm size related to effective new technology adoption and credit constraint [60], information flows in social learning of Indian rice and wheat technology revolution [61], technology policy function [62], impact assessment of technology intervention [63], and effects of improved agricultural technologies [64].

The \#6 cluster presents the driving force of green building technologies adoption and existing barriers in the construction industry. The research subjects are mainly about designers' adoption behaviours [65], driving force [10], and barriers of green building [66]. New engineering applications of green water technologies [67], green roof technology [68], green wall technology [69], and "green concrete" concept [70] are discussed in this cluster.

The \#7 cluster focuses on environmental negative impact control, such as water pollution and solid waste disposal and recycling problems. This cluster includes research subjects of green chemistry, environmental assessment, environmental compatibility, paper mill waste, and municipal solid waste. Modern industrial production inevitably comes up with undesirable output, even some pollutive and poisonous substance. Poliakoff (2007) contributed with unsustainable chemical manufacturing and 12 modern principles of green chemistry [71]. Green technologies are developed to realise removal of heavy metals, cyanobacteria, and other hazardous material in water $[72,73]$. Some novel processing and methods have also been presented to deal with solid waste, such as industrial and municipal solid waste [74].
The \#8 cluster reflects the functional materials with unique characterisation and thermal hazard evaluation. The research subjects are mainly about organic peroxide, scanning calorimetry, incompatible material, and thermal hazard. Newly found material characteristics, effective processing adjustment, and novel monitoring tools have been presented. Topics include ionic liquids with unique advantages showing higher selectivity, fast rates, and greater enzyme stability [75]; organic synthesis using microreactor technology having better thermal stability than traditional batch synthesis [76]; polylactide, as packaging material, being suitable for industrial usage, as well as its environmental implications [77]; and for thermal hazard, some novel calorimetric tests and simulation evaluating methods have been presented $[78,79]$.

The \#9 cluster concentrates on biological materials and engineering applications. It includes research subjects of alginate, bacterial inactivation, silica gel, catalyst, and immobilisation. Several highly cited papers are about microalgae encapsulation technology [80], green biocides [81], encapsulation in chitosan-based nanomatrix [82], and polyphenol recovery from pomegranate peels [83].

\section{Conclusions and Policy Implications}

Green technology is seemed to be used increasingly widely in different disciplines. This study uses knowledge mapping tools of CiteSpace and VOSviewer software to examine the development of green technology theme. We find that green technology concept came into being in the 1960s and became gradually popular in the 2000s. The research interest of green technology has been growing dramatically in the recent decade, with a sharp increase in published research papers and citation records.

Of the total 1136 green technology papers covering 149 research fields, the top three fields are environmental sciences, green sustainable science technology, and engineering environmental, and there exists about a quarter ratio of the total sample literature about environmental sciences. We can expect that more and more green technologies will be developed in the near future. From the cited journals of green technology, we find that the top 10 journals are Journal of Cleaner Production, Resources Conservation and Recycling, Environmental Science and Technology, Science, Journal of Hazardous Materials, Industrial and Engineering Chemistry Research, Bioresource Technology, Journal of Chemical Technology and Biotechnology, Chemical Review, and MIS Quarterly, with the use of parameter of centrality and publishing number. In the WoS database, 13 highly cited papers are related to the theme of green technology from 2009 to 2020, and they can be ascribed to chemistry, engineering, economics and business, and geosciences fields.

From the co-authorship analysis of green technology, we find that the network of research cooperation is quite weak. Only three little networks are labelled with different colours. From the country and institution analysis, we find that developed countries (the USA, England, etc.) and developing countries (China, Malaysia, etc.) have quite a few documents of green technology, and according to the parameter of $\mathrm{CN}$ 
and total link strength value, we obtain the top 15 counties. After the institution analysis of the green technology literature, 12 important institutions in 8 countries are recognised, but no dominant institutions have become eccentric. We find that they perform their research quite independently. In the knowledge mapping of cluster analysis, 10 keyword clusters of green technology papers are in the WoS database and three clusters are of economical theme, five clusters are of engineering application, and two clusters are of chemical issues.

In the future, we should strengthen the achievements of green technology progress, promote the level of innovation, and accelerate the regional flow of innovation factors. We should solve the bottleneck of green technology development of high-levelled human, material, and financial resources; focus on the "double base" construction to address key technical problems affecting industrial development, and break through the "neck" technical problems. At the same time, administrative departments should strengthen financial support for high-quality economic development; enhance the efficiency of financial investment in green technology and industry; and increase the auditing and inspection intensity of the use of financial investment funds to improve the interactive quality of green technological progress, financial investment, economic quality, and development level.

\section{Data Availability}

This paper is analysed through previous literature texts, and the text data are available.

\section{Conflicts of Interest}

The authors declare no conflicts of interest.

\section{Acknowledgments}

This work was supported by the financial projects funded by Jiangsu Federation of Social Sciences (Grant no. 21SCC-24).

\section{References}

[1] W. Bascom, "African material culture, technology and ecological adaption," Annals of the New York Academy of Sciences, vol. 96, pp. 581-589, 1962.

[2] K. Zhong, P. Wang, J. Pei, J. Pu, Z. Han, and J. Xu, "Multiobjective optimization regarding vehicles and power grids," Wireless Communications and Mobile Computing, vol. 2021, Article ID 5552626, 6 pages, 2021.

[3] R. Burke, "Green revolution technologies and farm class in Mexico," Economic Development and Cultural Change, vol. 28, pp. 135-154, 1979.

[4] T. Bayri and W. Furtan, "The impact of new wheat technology on income distribution: a green revolution case study, Turkey,1960-1983," Economic Development and Cultural Change, vol. 38, pp. 113-122, 1989.

[5] U. Khanal, C. Wilson, S. Shankar, V. Hoang, and B. Lee, "Farm performance analysis: technical efficiencies and technology gaps of Nepalese farmers in different agro-ecological regions," Land Use Policy, vol. 76, pp. 645-653, 2018.
[6] X. Su, P. Chiang, S. Pan et al., "Systematic approach to evaluating environmental and ecological technologies for wastewater treatment," Chemosphere, vol. 218, pp. 778-792, 2019.

[7] P. Grenni, A. Caracciolo, L. Mariani et al., "Effectiveness of a new green technology for metal removal from contaminated water," Microchemical Journal, vol. 147, pp. 1010-1020, 2019.

[8] S. Annamalai, M. Santhanam, S. Selvaraj, M. Sundaram, K. Pandian, and M. Pazos, "Green technology: bio-stimulation by an electric field for textile reactive dye contaminated agricultural soil," The Science of the Total Environment, vol. 624, pp. 1649-1657, 2018.

[9] D. Snoonian, "How green buildings are smarter and safer -energy-saving technology can have unexpected side benefits for building safety and intelligence," Architectural Record, vol. 191, pp. 100-104, 2003.

[10] A. Darko, A. Chan, S. Gyamfi, A. Olanipekun, B. He, and $\mathrm{Y}$. Yu, "Driving forces for green building technologies adoption in the construction industry: Ghanaian perspective," Building and Environment, vol. 125, pp. 206-215, 2017.

[11] C. Bishop, "Surface engineering - a green technology," Transactions of the Institute of Metal Finishing, vol. 81, pp. 13-18, 2003.

[12] Z. Guo, Y. Sun, S. Pan, and P. Chiang, "Integration of green energy and advanced energy-efficient technologies for municipal wastewater treatment plants," International Journal of Environmental Research and Public Health, vol. 16, p. 1282, 2019.

[13] J Si, L. Marjanovic-Halburd, F. Nasiri, and S. Bell, “Assessment of building-integrated green technologies: a review and case study on applications of Multi-Criteria Decision Making (MCDM) method," Sustainable Cities and Society, vol. 27, pp. 106-115, 2016.

[14] A. Pieczynska, A. Borzyszkowska, and A. Ofiarska, "Removal of cytostatic drugs by AOPs: a review of applied processes in the context of green technology," Critical Reviews in Environmental Science and Technology, vol. 47, pp. 1282-1335, 2017.

[15] F. AlKhawli, M. Pateiro, R. Dominguez et al., "Innovative green technologies of intensification for valorization of seafood and their by-products," Marine Drugs, vol. 17, pp. 1-20, 2019.

[16] N. van Eck and L. Waltman, "Software survey: VOSviewer, a computer program for bibliometric mapping," Scientometrics, vol. 84, pp. 523-538, 2010.

[17] X. Li, E. Ma, and H. Qu, "Knowledge mapping of hospitality research - A visual analysis using CiteSpace," International Journal of Hospitality Management, vol. 60, pp. 77-93, 2017.

[18] H. Chen, Y. Feng, S. Li, Y. Zhang, and X. Yang, "Bibliometric analysis of theme evolution and future research trends of the type a personality," Personality and Individual Differences, vol. 150, pp. 1-20, 2019.

[19] C. Chen, "Science mapping: a systematic review of the literature," Journal of Data and Information Science, vol. 2, pp. 1-40, 2017.

[20] M. Emamjomeh, "Electrocoagulation as a green technology for phosphate removal from river water," Separation and Purification Technology, vol. 217, p. 85, 2019.

[21] M. de Melo, A. Silvestre, and C. Silva, "Supercritical fluid extraction of vegetable matrices: applications, trends and future perspectives of a convincing green technology," The Journal of Supercritical Fluids, vol. 92, pp. 115-176, 2014.

[22] Y. Dai, J. van Spronsen, G. Witkamp, R. Verpoorte, and Y. Choi, "Natural deep eutectic solvents as new potential 
media for green technology," Analytical Chemical Acta, vol. 766, pp. 61-68, 2013.

[23] Z. Helwani, M. Othman, N. Aziz, W. Fernando, and J. Kim, "Technologies for production of biodiesel focusing on green catalytic techniques: a review," Fuel Processing Technology, vol. 90, pp. 1502-1514, 2009.

[24] X. Xu, P. He, H. Xu, and Q. Zhang, "Supply chain coordination with green technology under cap-and-trade regulation," International Journal of Production Economics, vol. 183, pp. 433-442, 2017.

[25] C. Neoh, Z. Noor, N. Mutamim, and C. Lim, "Green technology in wastewater treatment technologies: integration of membrane bioreactor with various wastewater treatment systems," Chemical Engineering Journal, vol. 283, pp. 582-594, 2016.

[26] M. Santamouris, "Cooling the cities - a review of reflective and green roof mitigation technologies to fight heat island and improve comfort in urban environments," Solar Energy, vol. 103, pp. 682-703, 2014.

[27] D. Krass, T. Nedorezov, and A. Ovchinnikov, "Environmental taxes and the choice of green technology," Production and Operations Management, vol. 22, pp. 1035-1055, 2013.

[28] M. Song and S. Wang, "Market competition, green technology progress and comparative advantages in China," Management Decision, vol. 56, pp. 188-203, 2018.

[29] M. Cohen, R. Lobel, and G. Perakis, "The impact of demand uncertainty on consumer subsidies for green technology adoption," Management Science, vol. 62, pp. 1235-1258, 2016.

[30] T. Schiederig, F. Tietze, and C. Herstatt, "Green innovation in technology and innovation management - an exploratory literature review," Management Science, vol. 42, pp. 180-192, 2012.

[31] K. Gallagher and E. Muehlegger, "Giving green to get green? Incentives and consumer adoption of hybrid vehicle technology," Journal of Environmental Economics and Management, vol. 61, pp. 1-15, 2011.

[32] J. Hein, K. Mizell, A. Koschinsky, and T. Conrad, "Deepocean mineral deposits as a source of critical metals for highand green-technology applications: comparison with landbased resources," Ore Geology Reviews, vol. 51, pp. 1-14, 2013.

[33] A. Darko, A. Chan, E. Ameyaw, B. He, and A. Olanipekun, "Examining issues influencing green building technologies adoption: the United States green building experts' perspectives," Energy and Buildings, vol. 144, pp. 320-332, 2017.

[34] A. Darko, A. Chan, Y. Yang, M. Shan, B. He, and Z. Gou, "Influences of barriers, drivers, and promotion strategies on green building technologies adoption in developing countries: the Ghanaian case," Journal of Cleaner Production, vol. 200, pp. 687-703, 2018.

[35] N. Adnan, S. Nordin, and M. Ali, "A solution for the sunset industry: adoption of green fertilizer technology amongst Malaysian paddy farmers," Land Use Policy, vol. 79, pp. 575-584, 2018.

[36] N. Adnan, S. Nordin, M. Bahruddin, and A. Tareq, "A stateof-the-art review on facilitating sustainable agriculture through green fertilizer technology adoption: assessing farmers behavior," Trends in Food Science \& Technology, vol. 86, pp. 439-452, 2019.

[37] Y. Zhang, T. Gan, H. Hu et al., "Green technology for the preparation of high fatty acid starch esters: solid-phase synthesis of starch laurate assisted by mechanical activation with stirring ball mill as reactor," Industrial \& Engineering Chemistry Research, vol. 53, pp. 2114-2120, 2014.
[38] S. Wade and Z. Ghahramani, "Bayesian cluster analysis: point estimation and credible balls (with discussion)," Bayesian Analysis, vol. 13, no. 2, pp. 559-626, 2018.

[39] B. Liu, H. Chen, and X. Huang, "Map changes and theme evolution in work hours: a co-word analysis," International Journal of Environmental Research and Public Health, vol. 15, no. 5, p. 1039, 2018.

[40] W. Birger, "A resource-based view of the firm," Strategic Management Journal, vol. 5, pp. 171-180, 1984.

[41] T. Jenkin, J. Webster, and L. McShane, "An agenda for "Green" information technology and systems research," Information and Organization, vol. 21, pp. 17-40, 2011.

[42] S. Vachon, "Green supply chain practices and the selection of environmental technologies," International Journal of Production Research, vol. 45, pp. 4357-4379, 2007.

[43] V. Dao, I. Langella, and J. Carbo, "From green to sustainability: information Technology and an integrated sustainability framework," The Journal of Strategic Information Systems, vol. 20, pp. 63-79, 2011.

[44] N. Muradov and T. Veziroglu, "Green path from fossil-based to hydrogen economy: an overview of carbon-neutral technologies," International Journal of Hydrogen Energy, vol. 33, pp. 6804-6839, 2008.

[45] M. Song, W. Zheng, and S. Wang, "Measuring green technology progress in large-scale thermoelectric enterprises based on Malmquist-Luenberger life cycle assessment," Resources, Conservation and Recycling, vol. 122, pp. 261-269, 2017.

[46] B. Cao and S. Wang, "Opening up, international trade, and green technology progress," Journal of Cleaner Production, vol. 142, pp. 1002-1012, 2017.

[47] A. Naqi and J. Jang, "Recent progress in green cement technology utilizing low-carbon emission fuels and raw materials: a review," Sustainability, vol. 11, pp. 537-555, 2019.

[48] T. Chen, Y. Yang, H. Zhang, H. Kim, and K. Horneman, "Network energy saving technologies for green wireless access networks," "IEEE Wireless Communications, vol. 18, pp. 30-38, 2011.

[49] R Bolla, F. Davoli, R. Bruschi, K. Christensen, F. Cucchietti, and S. Singh, "The potential impact of green technologies in next-generation wireline networks: is there room for energy saving optimization?" IEEE Communications Magazine, vol. 49, pp. 80-86, 2011.

[50] J. Viitanen and R. Kingston, "Smart cities and green growth: outsourcing democratic and environmental resilience to the global technology sector," Environment and Planning A-Economy and Space, vol. 46, pp. 803-819, 2014.

[51] A. Felipe, M. Ortuno, G. Righini, and G. Tirado, "A heuristic approach for the green vehicle routing problem with multiple technologies and partial recharges," Transportation Research Part E: Logistics and Transportation Review, vol. 71, pp. 111128, 2014.

[52] P. Flathman and G. Lanza, "Phytoremediation: current views on an emerging green technology," Journal of Soil Contamination, vol. 7, pp. 415-432, 1998.

[53] C. Huang, M. Miao, B. Jiang, S. Cui, X. Jia, and T. Zhang, "Polysaccharides modification through green technology: role of ultrasonication towards improving physicochemical properties of (1-3) (1-6)-alpha-D-glucans," Food Hydrocolloids, vol. 50, pp. 166-173, 2015.

[54] V. Sharma, R. Zboril, and R. Varma, "Ferrates: greener oxidants with multimodal action in water treatment technologies," Accounts of Chemical Research, vol. 48, pp. 182-191, 2015. 
[55] S. Novalin and T. Zweckmair, "Renewable resources - green biorefinery: separation of valuable substances from fluidfractions by means of membrane technology," Biofuels Bioproducts\&Biorefining-BIOFPR, vol. 3, pp. 20-27, 2009.

[56] N. Baig, F. Alghunaimi, and T. Saleh, "Hydrophobic and oleophilic carbon nanofiber impregnated styrofoam for oil and water separation: a green technology," Chemical Engineering Journal, vol. 360, pp. 1613-1622, 2019.

[57] B. Tiwari, "Ultrasound: a clean, green extraction technology," TRAC Trends in Analytical Chemistry, vol. 71, pp. 100-109, 2015.

[58] S. Kumar, S. Prasad, R. Banerjee, D. Agarwal, K. Kulkarni, and K. Ramesh, "Green solvents and technologies for oil extraction from oilseeds," Chemistry Central Journal, vol. 11, pp. 1-7, 2017.

[59] M. Bubalo, S. Vidovic, I. Redovnikovic, and S. Jokic, "Green solvents for green technologies," Journal of Chemical Technology and Biotechnology, vol. 90, no. 9, pp. 1631-1639, 2015.

[60] G. Feder and G. Omara, "Farm size and the diffusion of green revolution technology," Economic Development and Cultural Change, vol. 30, pp. 59-76, 1981.

[61] K. Munshi, "Social learning in a heterogeneous population: technology diffusion in the Indian Green Revolution," Journal of Development Economics, vol. 73, pp. 185-213, 2004.

[62] K. Otsuka and Y. Kijima, "Technology policies for a green revolution and agricultural transformation in Africa," Journal of African Economies, vol. 19, pp. 60-76, 2010.

[63] M. Degraft-Johnson, A. Suzuki, T. Sakurai, and K. Otsuka, "On the transferability of the Asian rice green revolution to rainfed areas in sub-Saharan Africa: an assessment of technology intervention in Northern Ghana," Agricultural Economics, vol. 45, pp. 555-570, 2014.

[64] J. Ariga, E. Mabaya, M. Waithaka, and M. Wanzala-Mlobela, "Can improved agricultural technologies spur a green revolution in Africa? A multi-country analysis of seed and fertilizer delivery systems," Agricultural Economics, vol. 50, pp. 63-74, 2019.

[65] W. Wang, S. Zhang, Y. Su, and X. Deng, "Key factors to green building technologies adoption in developing countries: the perspective of Chinese designers," Sustainability, vol. 10, no. 11, pp. 1-22, 2018.

[66] A. Chan, A. Darko, E. Ameyaw, and D. Owusu-Manu, "Barriers affecting the adoption of green building technologies," Journal of Management in Engineering, vol. 33, pp. 1-12, 2017.

[67] C. Frayne, "Green water technologies and resource management for water system heat-transfer applications int the built environment," Journal of Green Building, vol. 5, no. 1, pp. 56-67, 2010.

[68] I. Ziogou, A. Michopoulos, V. Voulgari, and T. Zachariadis, "Implementation of green roof technology in residential buildings and neighborhoods of Cyprus," Sustainable Cities and Society, vol. 40, pp. 233-243, 2018.

[69] F. Torpy, M. Zavattaro, and P. Irga, "Green wall technology for the phytoremediation of indoor air: a system for the reduction of high CO2 concentrations," Air Quality Atmosphere and Health, vol. 10, pp. 575-585, 2017.

[70] P. Duxson, J. L. Provis, G. C. Lukey, and J. S. Van Deventer, "The role of inorganic polymer technology in the development of green concrete," Cement and Concrete Research, vol. 37, pp. 1590-1597, 2007.

[71] M. poliakoff and P. license, "Sustainable technology -Green chemistry," Nature, vol. 450, pp. 810-812, 2007.
[72] E. Salama, H. Roh, S. Dev et al., "Algae as a green technology for heavy metals removal from various wastewater," World Journal of Microbiology and Biotechnology, vol. 35, p. 75, 2019.

[73] V. Sharma, L. Chen, B. Marsalek, R. Zboril, K. O'Shea, and D. Dionysiou, "Iron based sustainable greener technologies to treat cyanobacteria and microcystin-LR in water," Water Science and Technology: Water Supply, vol. 17, pp. 107-114, 2017.

[74] Y. Najjar and D. Waite, "Energy conservation and waste utilization in the cement industry serve the green technology and environment," International Journal of Sustainable Engineering, vol. 9, pp. 3-10, 2016.

[75] K. Zhong, Y. Wang, J. Pei, S. Tang, and Z. Han, "Super efficiency SBM-DEA and neural network for performance evaluation," Information Processing \& Management, vol. 58, no. 6, Article ID 102728, 2021.

[76] B. Mason, K. Price, J. Steinbacher, A. Bogdan, and D. McQuade, "Greener approaches to organic synthesis using microreactor technology," Chemical Reviews, vol. 107, pp. 2300-2318, 2007.

[77] J. Ahmed and S. Varshney, "Polylactides-chemistry, properties and green packaging technology: a review," International Journal of Food Properties, vol. 14, pp. 37-58, 2011.

[78] J. Tseng and C. Lin, "Green thermal analysis technology for evaluating the thermal hazard of Di-tert-butyl peroxide," Industrial \& Engineering Chemistry Research, vol. 50, pp. 9487-9494, 2011.

[79] J. Tseng, J. Lin, C. Lee, and C. Lin, "Prediction of TMCH thermal hazard with various calorimetric tests by green thermal analysis technology," AIChE Journal, vol. 58, pp. 3792-3798, 2012.

[80] J. Desmet, C. Meunier, E. Danloy et al., "Green and sustainable production of high value compounds via a microalgae encapsulation technology that relies on $\mathrm{CO} 2$ as a principle reactant," Journal of Materials Chemistry, vol. 2, pp. 2056020569, 2014.

[81] M. Ashraf, S. Ullah, I. Ahmad, A. Qureshi, K. Balkhair, and M. Rehman, "Green biocides, a promising technology: current and future applications to industry and industrial processes," Journal of the Science of Food and Agriculture, vol. 94, pp. 388-403, 2014.

[82] S. Das, V. Singh, A. Dwivedy et al., "Encapsulation in chitosan-based nanomatrix as an efficient green technology to boost the antimicrobial, antioxidant and in situ efficacy of Coriandrum sativum essential oil," International Journal of Biological Macromolecules, vol. 133, pp. 294-305, 2019.

[83] H. Rajha, T. Mhanna, S. ElKantar, A. ElKhoury, N. Louka, and R. Maroun, "Innovative process of polyphenol recovery from pomegranate peels by combining green deep eutectic solvents and a new infrared technology," LWT-Food Science and Technology, vol. 111, pp. 138-146, 2019. 